EKONOMIA I FINANSE

DOI: $10.18276 /$ sip.2019.55-10

Agnieszka Szewczyk*

Uniwersytet Szczeciński

\title{
SOCIAL FINANCING - CAPITAL FOR PROJECTS OF THE EXAMPLE OF CROWDFUNDING PLATFORMS IN POLAND
}

\begin{abstract}
The main objective of this study is to analyse social financing of projects and the social perception of this process in Poland. The specific objective is to confirm or reject six selected hypotheses about social financing. The author uses the diagnostic survey method, statistical methods and the technique of surveying and examining documents. The questionnaire survey was both online and direct. The electronic documents of www.wspieram.to website were also examined. Five hypotheses have been verified positively.
\end{abstract}

Keywords: crowdfunding, projects, www.wspieram.to

\section{Introduction}

Crowdfunding, or in other words social financing, is a method of gaining capital from users by means of the Internet for realization of projects in which users in return are offered returnable services of different kinds. Due to a relatively short history of this way of gaining resources and its quick popularization and development, the state of research on crowdfunding is limited, especially in reference to Polish sources, re-

\footnotetext{
* ORCID: 0000-0002-3050-4192,E-mail: agnieszka.szewczyk@usz.edu.pl
} 
ferring to Polish services and crowdfunding initiatives. Moreover, this phenomenon is characterized by a large variability, in a short time new websites dealing with social financing, gaining a considerable popularity or falling; new models of activity, legal regulations.

The main objective of this study is to analyse social financing of projects and the social perception of this process in Poland. The specific objective is to confirm or reject six selected hypotheses about social financing. This paper presents a synthetic outline concerning selected issues and methods of crowdfunding as well as the results of the research conducted according to the presented methodology referring to problems of functioning of one of the greatest Polish crowdfunding platforms Wspieram.to, and the social perception of the phenomenon of crowdfunding in Poland.

\section{Crowdfunding or, in other words, social financing}

\subsection{The core of crowdfunding}

The word "crowdfunding" is a neologism, resulting from the connection of two English words "crowd" and "funding", i.e. financing. It can be translated as "bottomup" financing or "financing through the Internet". Due to the degree of reflection of the activity on the Internet, as enterprises are not financed by the entire Internet network but by a group of its users, it is proper to use the translation "social financing" or "community financing" (Brunello, 2016, pp. 26-27).

Crowdfunding can be most generally defined as gaining financial means for realization of enterprises through the Internet in exchange for certain advantages offered to the investors. A detailed definition of crowdfunding becomes exceptionally essential for distinguishing this mechanism from gaining funds in a seemingly similar manner, i.e. social financing cannot mean any raising micropayments from many individuals, for example buying by investors individual shares of companies entering the stock exchange (Król, 2013, p. 24).

At the same time, social financing is not the substance but a tool defined by Alessandro Brunello as "the process of co-operation of a bigger number of individuals who decide about assigning their own money, in principle small sums, to support efforts, projects and visions of other private individuals but also firms, enterprises and organizations" (Brunello, 2016, p. 26). 
The definitions provided by various authors, e.g. Kozioł-Nadolna (2015, pp. 672-674), Boniewicz (2015, p. 55), Malinowski (2017, p. 8), Grzybowska (2016, p. 69), indicate the essence of crowdfunding as financial support for a numerous group of dispersed and differentiated users of Internet websites for different enterprises, e.g. business culture, art, sport or media circles, started in order to obtain certain advantages. The existence of those advantages, certain returnable services resulting from fulfilment of given enterprise decides about classifying enterprises as crowdfunding projects sensu stricto.

\subsection{Characteristics and models of social financing}

Listed below are the characteristic features of social financing whose joint fulfilment allows clear separation of crowdfunding from other forms of gaining financial means:

- the objective of the project, whether personal, business or public, is clearly specified, the intended use of resources and the effects of their spending are well-known;

- money practically always appear in a dematerialized form with financing based on delivery of cash without any possibility to support with other resources;

- a wide community of addressees of the information about the project; the knowledge is available for a very large group of people, mostly for every person they will reach;

- open call - lack of limitations in access to project support, such a possibility is presented in an open manner;

- ICT - the process of capital collection takes place with the utilization of data communication solutions;

- capital collection takes place on better conditions for a given project initiator than those generally available on the market;

- there appear returnable services in the different forms, but not only of an emotional character, for every person or business supporting financially the project (Król, 2013, pp. 25-26).

Nowadays crowdfunding is considered as an independent phenomenon (KoziołNadolna, 2015, p. 672). According to the report of the Polish Agency for Business Development (PARP), "crowdsourcing is based mainly on the flow of knowledge, skills or ready projects from the Internet users to a subject seeking a given solution", whereas crowdfunding is defined as "invitation for Internet users to finance an enterprise reported on an Internet platform" (Boniewicz, 2015, p. 55). 
Depending on the author, different divisions of crowdfunding models can be observed. The most important categories are as follows:

- reward based crowdfunding (a sponsor model) - participants are rewarded with prizes for their financial support for a project;

- equity based crowdfunding (shareholding crowdfunding) - network users transfer their financial resources through web platforms for which they receive a part of the subject of the campaign, for example in the form of shares;

- social lending and micro finance (social loans and microloans; a loan model) - direct lending of financial resources from the Internet community without the agency of banks and financial institutions (Koziol-Nadolna, 2015, pp. 673-674);

- models based on donations (non-reward based crowdfunding) where individuals are motivated to spend money by doing good and non-expectation of returnable services (Król, 2013, p. 29); Katarzyna Kozioł-Nadolna classifies such models with reward-based crowdfunding as part of a wider aggregate of donation models.

- mixed models (mixed solutions), which combine solutions of the above mentioned models (Kozioł-Nadolna, 2015, p. 674).

\section{An analysis of the functioning and perception of social financing}

\subsection{The research methodology}

The subject of the research is crowdfunding in Poland and its aim is to analyse the functioning and the social perception of social financing of projects and the social perception of this process in Poland. Provided with the data of 2013-2015 concerning the activity of the crowdfunding platform called Wspieram.to and the data from the diagnostic survey, the following hypotheses were assumed:

1) the period of 2013-2015 saw a significant increase in the number of completed projects on Wspieram.to web platform;

2) the rate of changes in 2013-2015 regarding the number of completed projects and the quantity of paid funds was positive for Wspieram.to web platform;

3) the structure of projects in Wspieram.to web platform shows a large differentiation according to their category; 
4) the awareness of the existence of crowdfunding as a method of financing projects is higher in younger individuals with higher education;

5) more individuals understanding the meaning of the name "crowdfunding" perceive the phenomenon positively than negatively;

6) declared ignorance of the notion of crowdfunding does not determine the lack of willingness to participate in projects based on crowdfunding.

The methods used in this research were statistical methods and the diagnostic survey method. The example used in the analysis of the functioning of crowdfunding in Poland was Wspieram.to, which is one of the greatest Polish reward-based crowdfunding websites as regards the number of completed projects and the total sum of collected funds. For this purpose the research used statistical data documents concerning projects publicly made available in the electronic form by the website. Then, both online and direct questionnaire survey were used for the purposes of an analysis of the social perception of crowdfunding in Poland. The questionnaire consisted of 13 closed questions, one half-open question and one open question. 215 responses were obtained. This sample is sufficient for the analysis of the assumed hypotheses. It was selected in a manner which guarantees a variety of respondents and the reliability of research, which is indicated by a so-called certificate attached to the questionnaire. The questionnaire was carried out by Christopher Boboryko, a student of Szczecin University

\subsection{Analysis of data from Wspieram.to web platform}

The levels of payments, numbers of supporters, total numbers of campaign, numbers of successful campaigns and percentages of successful campaigns among the total number of campaigns for Wspieram.to web platform were presented in Table 1.

Table 1 . The activity of Wspieram.to web platform

\begin{tabular}{|l|l|c|c|c|c|}
\cline { 2 - 5 } & Paid-in sum (PLN) & $\begin{array}{c}\text { Number of new } \\
\text { supporters }\end{array}$ & $\begin{array}{c}\text { Number of started } \\
\text { campaigns }\end{array}$ & $\begin{array}{c}\text { Numbers } \\
\text { of successful } \\
\text { campaigns }\end{array}$ & $\begin{array}{c}\text { Percentage } \\
\text { of successful } \\
\text { campaigns (\%) }\end{array}$ \\
\hline 2013 & $280,000.00$ & 4710 & 101 & 30 & 29.70 \\
\hline 2014 & $1,800,000.00$ & 26234 & 222 & 106 & 47.75 \\
\hline 2015 & $6,300,000.00$ & 40420 & 520 & 332 & 63.85 \\
\hline
\end{tabular}


Table 1 allows for accumulative values appearing in a given year without any references to previous years. The field "Paid-in sum" includes a sum of all payments for projects in a given year regardless the fact if they were successful campaigns. The field "Number of new supporters" presents the number of new users supporting projects in a given year without taking into account investors form earlier years and those returning to the service. "Number of started campaigns" refers to all campaigns started in a given year regardless their status after activation, i.e. whether they succeeded. "The number of successful campaigns" indicates only those projects which ended with raising funds determined in the financing aim, which is not tantamount with realization of a project understood as fulfilment of assumptions specified in the project, i.e. manufacturing the object of the project, delivering rewards to supporters). The field "Percentage of successful campaigns" presents proportions between the number of successful campaigns and the total number of campaigns, which are the indicator of the efficiency of designers and crowdfunding platforms in gaining resources with this method.

The research used one-based indexes counted according to the formula $i_{t}=\frac{y_{t}}{t_{t_{0}}}$ and with chain indexes counted as $i_{t-1}=\frac{y_{t}}{y_{t-1}}$ The average rate of changes was counted according to the formula $\bar{T}=\left(\bar{i}_{t-1}-1\right) \times 100 \%$.

The quantity of payments significantly increased in years 2013-2015. In comparison with 2013, in 2014 there was a growth by $543 \%$, and in 2015 by about $2150 \%$. When comparing 2014 with 2015, a growth by $250 \%$ was observed. The average rate of changes in 2013-2015 was 396\%, which means that in the examined period the quantity of payments grew on average by $396 \%$ every year. This indicates a very quick development of Wspieram.to web platform. This can be caused by a rapid growth of the popularity of crowdfunding in Poland in the indicated time and building on the Polish market a position of community financing by Wspieram.to as a recognizable and popular brand.

Also, as regards the number of new supporters there was a rapid growth in 2013 2015. In comparison to 2013, in 2014 there was an increase in the number of users by about $457 \%$, in 2015 in comparison to 2013 there was a growth by $758 \%$, and in comparison to 2014 the number of users in 2015 increased by $54 \%$. The average rate of changes was $256 \%$ - on average every year projects were supported by $256 \%$ users more. The increase of the number of the platform users, like in the case of the growth of the quantity of payments, can result from its high market position. However, this increase was less rapid than in the case of the sum of payments, which may be caused by the differentiation of the quantity of funds paid by users for realization of given projects (a possibility of paying high sums). 
In the examined period there was an increase in the total number of campaigns started and successful campaigns. In comparison to 2013 the number of started actions in 2014 increased by $120 \%$, yet in 2015 by $515 \%$. The number of started campaigns in 2015 in comparison to 2014 increased by 134\%. The average rate of changes of the number of started projects was $127 \%$ - on average every year the number of campaigns increased by 1.27 times. The average rate of changes was in this case lower than the average rate of changes of payments - the increase in the number of new actions was not proportional to the increase of payments. A possible reason is the occurrence of higher financing aims than earlier in new projects. The increase in the number of campaigns was not proportional to the growth of the number of new users, either; a lower average rate of changes of the number of started campaigns was observed. This can indicate a bigger commitment of users within the campaign a bigger number of supporters in individual campaigns.

The number of successful campaigns in 2015 increased by 1007\% in comparison to 2013 and by $213 \%$ in comparison to 2014. In 2014 there was a growth by $253 \%$ in comparison to the previous year. The average rate of changes of the number of successful campaigns on Wspieram.to web platform e in 2013-2015 was 233\% on average every year 2.33 campaigns more were successful. Changes in the percentage of successful campaigns among the total number of campaigns was presented in Table 2.

Table 2. Changes in the level of the efficiency of crowdfunding campaign in Wspieram.to web platform

\begin{tabular}{|l|c|c|c|}
\hline & $\begin{array}{c}\text { The percentage } \\
\text { of successful campaigns }\end{array}$ & One-based indexes & $\begin{array}{c}\text { Chain } \\
\text { indexes }\end{array}$ \\
\hline 2013 & 29.70 & 1.00 & - \\
\hline 2014 & 47.75 & 1.61 & 1.61 \\
\hline 2015 & 63.85 & 2.15 & 1.34 \\
\hline \multicolumn{2}{|c|}{ The average rate of changes $47 \%$} \\
\hline
\end{tabular}

The source: the author's study based on The third year of Wspieram.to.

In the examined period the percentages of successful campaigns in relation to the total number of campaigns increased on average by $47 \%$ annually. In 2014 there was a growth of the efficiency by $61 \%$ in relation to the previous year, however, in 2015 by $115 \%$ (in relation to 2013 ) and $34 \%$ (in relation to 2014). 
Another interesting issue is the analysis of crowdfunding campaigns on the discussed website according to the category of projects. The details are introduced in Table 3.

Table 3. The statistics of the crowdfunding campaign of Wspieram.to web platform according to the category of projects in September 2017

\begin{tabular}{|c|c|c|c|c|c|c|c|c|}
\hline Category & 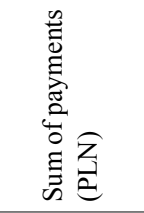 & 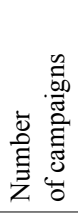 & 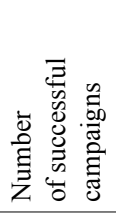 & 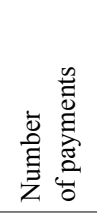 & 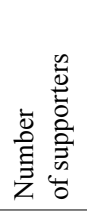 & 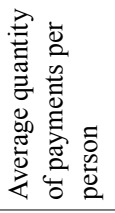 & 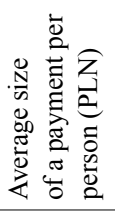 & 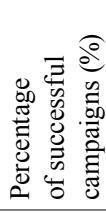 \\
\hline Music & 1524997 & 225 & 110 & 22408 & 14044 & 1.6 & 68.06 & 48.89 \\
\hline $\begin{array}{l}\text { Book/ } \\
\text { periodical }\end{array}$ & 798807 & 145 & 62 & 11185 & 9482 & 1.2 & 71.42 & 42.76 \\
\hline Comic books & 199148 & 25 & 18 & 3462 & 1767 & 2.0 & 57.52 & 72.00 \\
\hline $\begin{array}{l}\text { Computer } \\
\text { games }\end{array}$ & 202517 & 44 & 13 & 4130 & 3412 & 1.2 & 49.04 & 29.55 \\
\hline $\begin{array}{l}\text { Analogue } \\
\text { games }\end{array}$ & 4089908 & 119 & 92 & 35116 & 9224 & 3.8 & 116.47 & 77.31 \\
\hline Initiatives & 2683190 & 143 & 74 & 30261 & 26065 & 1.2 & 88.67 & 51.75 \\
\hline Event & 888670 & 63 & 28 & 6046 & 4178 & 1.4 & 146.98 & 44.44 \\
\hline $\begin{array}{l}\text { Movies/ } \\
\text { photography }\end{array}$ & 444131 & 71 & 24 & 4754 & 4334 & 1.1 & 93.42 & 33.80 \\
\hline Design & 511019 & 34 & 8 & 6187 & 5242 & 1.2 & 82.60 & 23.53 \\
\hline Cosplay & 25425 & 6 & 4 & 195 & 198 & 1.0 & 130.38 & 66.67 \\
\hline Education & 293761 & 44 & 16 & 2504 & 2005 & 1.2 & 117.32 & 36.36 \\
\hline Fashion & 50047 & 26 & 4 & 411 & 399 & 1.0 & 121.77 & 15.38 \\
\hline Theatre/dance & 153109 & 35 & 14 & 1919 & 1466 & 1.3 & 79.79 & 40.00 \\
\hline Technologies & 183486 & 43 & 8 & 2107 & 1896 & 1.1 & 87.08 & 18.60 \\
\hline Expeditions & 440137 & 69 & 27 & 3866 & 2981 & 1.3 & 113.85 & 39.13 \\
\hline Sport & 635997 & 122 & 33 & 4874 & 3926 & 1.2 & 130.49 & 27.05 \\
\hline Start-up & 222124 & 53 & 6 & 4567 & 3396 & 1.3 & 48.64 & 11.32 \\
\hline Total & 13346473 & 1267 & 541 & 143992 & 94015 & 1.5 & 93.00 & 42.70 \\
\hline
\end{tabular}

Source: the author's study based on https://wspieram.to/statystyki_kategorii.

The values presented in Table 3 are joint values, added up from the beginning of the activity of the website in 2013 .

In the analysis of structures, the standard deviation was used, counted as:

$$
S(x)=\sqrt{\frac{\sum(x-\bar{x})^{2}}{(n-1)}}
$$


and the variability coefficient counted according to the formula:

$$
V_{s(x)}=\frac{s(x)}{\bar{x}} \times 100
$$

The comparison of structures was carried out with the use of the indicator of structure resemblance, counted as: $w_{p}=\sum_{i=1}^{N} \min \left\{w_{i j}\right\}$, where $w_{i}=\frac{n_{i}}{N} \times 100$. The analysis of correlation was based on the Pearson linear correlation coefficient counted according to the formula: $r_{x y}=\frac{\operatorname{cov}(x, y)}{s(x) \times s(y)}$.

On average in 2017 financing categories in Wspieram.to web platform showed payments in the amount of 785087 PLN. Payments for categories deviated from the average on average by 1076317.07 PLN. There occurred a high variability of sums of payments in categories - at the level of $137 \%$. The highest sums of resources were observed in categories: 'analogue games', 'initiatives' and 'music'. The least was paid for projects in the category called 'cosplay'.

On average there were 74.5 campaigns started on the website in every category. The number of campaigns deviates from the average by $5 \%$ and shows a moderate variability at the level of $77 \%$. The most campaigns were carried out in categories 'music', 'book/periodical' and 'initiative'. The fewest campaigns were started in the category 'cosplay'.

Bringing the amount of payments and the number of campaigns to percentage values it is possible to comparison their structures. They are characterized with moderate resemblance at the level of $67.1 \%$. Most projects with the highest financing sums are in the category 'music'. The variability of the structure of the number of campaigns according to a category is smaller than the variability of the sum of payments. An example of a category in which a very high financing sum is not identical with an equally high number of campaigns are 'analogue games'. In spite of lower number of campaigns than in categories 'music' or 'initiatives', 'analogue games' obtained the highest sum of payments, at the same time showing the highest percentage of successful campaigns to campaigns altogether and the highest quantity of individual payments.

Measured as a percentage of successful campaigns among campaigns altogether in a given category, the campaign efficiency was $42.70 \%$ for all categories of the website. When examining the quantitative factors influencing the campaign success, linear correlation coefficients were counted in order to check which of the statistics shows the greatest correlation with the percentage of successful campaigns. The average amount of payment per person did not show in this instance any linear 
relationship (Pearson coefficient in the amount of approximately 0.15). An example of the lack of correlation are categories 'sport' and 'fashion' - despite relatively high payments the efficiency of projects was low (respectively: 130.49 PLN and 27.05\%; 121.77 PLN and $15.38 \%$ ), while at the relatively low average value of support of the category 'comic books' (57.52 PLN) - there occurred an efficiency above average in this section (72\%). The number of payments showed a slight correlation (0.27), and the quantity of payments and the sum of payments for the category moderate correlations $(0.50$ and 0.54$)$. A moderate correlation with the maximum value of the linear correlation coefficient -0.61 was shown by the average of the number of payments per person. An example of the operation of this correlation is the category 'analogue games'. The high average quantity of support by one user in this section (3.8) corresponds to an equally high percentage of successful campaigns among the total number of campaigns (77.31\%).

The data analysis concerning Wspieram.to web platform as an example of functioning of crowdfunding in Poland can confirm the hypotheses about the significant growth of the number of completed projects in 2013-2015 and the positive rate of changes regarding the number of completed projects and the quantity of paid-in resources. This is a proof of quick development of the platform from the beginning of its existence associated with the growth of popularity of this type of financing projects in Poland. The growing efficiency of campaigns on the web portal is also a proof of its progress and can be a good prognostic indicator both for creators of the web platform and potential new designers and investors.

The structure of projects realized in the website is characterized with a large differentiation regarding their category. Both in respect of the sum of payments, their average, the number of users involved in campaigns and the degree of this commitment, campaigns organized by Wspieram.to are characterized with a significant variety. Moreover, the number of factors affecting categories of a campaign makes it difficult to show which is 'the most popular'. This is dependent from the individually accepted assessment factors. The highest sum of payments is not equal with the most numerous group of supporters, which does not need to correspond with greater chances for success of the campaign. It is exemplified by the 'cosplay' category which, in comparison with others shows a small number of projects, the sum of payments and the number of supporting users, however, it succeeded in completing 4 of 6 started enterprises while in, it would seem, a more popular category 'technology', with a higher sum of payments and a higher number of projects only 8 of 43 announced were completed. This suggests being careful in evaluating not 
only Wspieram.to but also other social financing websites on the basis of the statistics published by them, which given without the context are frequently used by them to promote their activity. Collecting and analysing the available data allowed distinguishing that as part of the category of Wspieram.to projects, the factor which affects the success of the campaign the most was users' returning to certain types of projects and willingness to make more than one payment.

\subsection{An analysis of the diagnostic survey}

The survey questionnaire divided into 6 sections (I-VI) included the following questions:

\section{Defining the respondent}

1. How often do you use the Internet? (6 possibilities)

2. Are you familiar with the notion of crowdfunding or social financing? (2 possibilities)

II. Perception of crowdfunding

1. What is the level of your knowledge of crowdfunding/social financing? (3 possibilities)

2. What are your feelings in relation to the discussed problem? (5 possibilities)

3. What do you think is the major disadvantage and/or advantage? (an open question)

4. Have you ever participated in a crowdfunding project as a supporter financing a campaign? (2 possibilities)

III. Participation in a crowdfunding project

5. In how many social financing projects have you participated? (5 possibilities)

6. What was an average sum of support for the project? (5 possibilities)

7. Are you inclined to participate in another project? (3 possibilities)

IV. Crowdfunding as an unknown phenomenon

8. Would you be willing to pay money online for the realization of a project which is interesting for you in exchange for obtaining a certain advantage? (3 possibilities)

V. Motivation for participation in a project

9. What is the major cause making you support a project? (9 possibilities)

VI. Particulars

10. Sex

11. Age 


\section{Place of residence}

13. Education

The questionnaire had a non-linear character. Depending on given answers respondents were directed to its other sections. This aims to distinguish subgroups of respondents to detailed research and avoid contradictions in given answers.

The table below includes selected figures from the research.

Table 4. Selected data from the diagnostic survey on perception of crowdfunding in Poland

\begin{tabular}{|c|l|c|}
\hline $\begin{array}{c}\text { Question } \\
\text { number }\end{array}$ & \multicolumn{1}{|c|}{ Most frequent responses } & $\begin{array}{c}\text { Greatest \% } \\
\text { of the answers }\end{array}$ \\
\hline 1 & I use the Internet every day & 95 \\
\hline 2 & Yes, I know this notion & 51 \\
\hline 3 & $\begin{array}{l}\text { The phenomenon, the financing method which is well-known to me, } \\
\text { but which I do not follow more closely }\end{array}$ & 41 \\
\hline 4 & I have positive feelings & 80 \\
\hline 5 & $\begin{array}{l}\text { The main advantage - an opportunity for development of small enterprises } \\
\text { without access to other sources of capital. The main disadvantage }-\end{array}$ & 60 \\
\hline 6 & risk of frauds and abuse & 45 \\
\hline 7 & I haven't participated in the project as a financing supporter & 38 \\
\hline 8 & The average sum of support is $20-50$ PLN & 62 \\
\hline 9 & I am willing to participate in on the following project & 56 \\
\hline 10 & I am willing to pay money online in exchange for obtaining advantages & 34 \\
\hline 11 & I want to help the project because its topic lies in the area of my interests & 62 \\
\hline 12 & Sex - female & 38 \\
\hline 13 & Age - 15-24 & 66 \\
\hline 14 & Place of residence - city above 50.000 inhabitants & 50 \\
\hline 15 & Education - primary & \\
\hline
\end{tabular}

Source: the author's own study.

The questionnaire survey has shown that one user does not have to be associated with a one-time support in one project. $71 \%$ respondents declaring their participation in projects made payments more than once. However, individuals who know the crowdfunding phenomenon and participate in campaigns are a minority among the respondents. The survey allows confirming the hypothesis according to which individuals aware of the existence of social financing have mostly positive opinions about it. The fact that most individuals who do not understand this notion declare also that they would be able to participate in the phenomenon on similar rules, indicates a possible growth of the popularity of crowdfunding together with its recognisability. However, crowdfunding is still not universally understood in Poland. There are dif- 
ferences between its being understood in various subgroups. The hypothesis about a higher awareness of crowdfunding among the respondents with higher education was confirmed, yet the hypotheses that this financing method is commonly known among younger individuals cannot be clearly confirmed. Even though respondents from the age group of 15-34 year olds most often declared that they know crowdfunding, however, in the group of 55 year olds and more did not declare it more seldom than the group of 35-54 year olds.

Taking into account the presented findings, it can be ascertained that crowdfunding as a source of capital for projects in Poland, despite its comparatively early development phase and visible problems can be more effective in the coming years, and its efficiency and popularity will grow together with development of project web platforms, improvement of approach to projects and the growth of social awareness. The attitude of potential users is positive as a rule and in the era of common Internet access it is only a matter of time before they are informed about a new manner of raising resources for enterprises and transition from the status of potential to active users of crowdfunding platforms.

\section{Conclusions}

The paper presents social financing, a source of capital for projects, with the use of examples of crowdfunding web platforms in Poland. Available literature was used to present definitions indicating the complex character of the crowdfunding phenomenon and the most frequent models of its functioning.

The statistical material of the primary and secondary character, i.e. the statistics of Wspieram.to website and the questionnaire, were used to analyze the functioning and perception of crowdfunding in Poland. Also, the paper presents formation of changes (2013-2015) in the basic quantities connected with the activity of one of the greatest Polish web portals of social financing as a reference point for the development of the domestic crowdfunding market and data concerning projects and their completion in a general perspective, in order to characterize the crowdfunding activity in practice. The paper also presents the structure of projects and sums of payments according to the subject matter of the enterprises. A questionnaire was used to examine respondents' feelings towards social financing and the degree of their knowledge on the subject. 
The most important conclusions include as follows:

- crowdfunding still can be defined as a new type of financing of enterprises and its popularity has been growing since its origin. Over time this phenomenon has become an object of an increasingly greater number of research and is described more extensively, however, it is still a wide field for analyses;

- crowdfunding projects are characterized with a large differentiation within financed categories and attain increasingly bigger sizes both in respect of their scope and gathered resources, yet the most frequent categories of projects do not need to be characterized with the highest payments; moreover, the efficiency of their financing is also growing;

- the questionnaire survey showed that individuals who know the notion of crowdfunding are still a minority, however, their participation in the entire group of all respondents is comparatively high and can increase in the following years;

- the analysed phenomenon is perceived mostly positively despite identified drawbacks of this method of raising funds, differentiated motives can lead to activating new users and increasing the awareness of crowdfunding in the society.

The subject matter of crowdfunding is still a wide field for research in many aspects both from the economic, social and technological perspective. It is advisable to observe and analyse this phenomenon in the future. With the passing of time it will be possible to verify the assumed forecasts and determine new developmental tendencies for this method of financing, which is nowadays a new and increasingly effective opportunity for individuals seeking possibilities to realize their ideas.

\section{References}

Boniewicz, A. (2015). Crowdfunding jako źródło finansowania pomysłów w Polsce. In: F. Milewski (Ed.), Tłum jako źródło wiedzy i kapitału (pp. 54-64). Warszawa: Polska Agencja Rozwoju Przedsiębiorczości.

Brunello, A. (2016). Crowdfunding. Podręcznik. Warszawa: Wydawnictwo CeDeWu.

Grzybowska, K. (2016). Crowdfunding nad Wisłą, czyli Polak potrafi wspierać. In: Raport. Trendy w polskim biznesie internetowym. Retrieved from https://businessinsider.com.pl/wiadomosci/trendy-w-polskim-biznesie-internetowym-raport/2m5hyqh (19.09.2017). 
Kozioł-Nadolna, K. (2015). Crowdfunding jako źródło finansowania innowacyjnych projektów. Finanse, Rynki Finansowe, Ubezpieczenia, 73, 671-683.

Król, K. (2013). Crowdfunding. Od pomystu do biznesu, dzięki społeczności. Warszawa: Crowdfunding.pl.

Malinowski, B. (2017). Przewodnik po polskich platformach crowdfundingowych. Która wybrać dla swojego projektu? Retrieved from http://mamstartup.pl/crowdfunding/11023/przewodnik-po-polskich-platformach-crowdfundingowych-ktora-wybracdla-swojego-projektu (19.09.2017).

Wspieram.to. The third year of Wspieram.to. Retrieved from https://wspieram.to/landing/ trzecirok/index.html (19.09.2017).

Wspieram.to. Retrieved from https://wspieram.to/statystyki_kategorii (19.09.2017).

\section{FINANSOWANIE SPOŁECZNOŚCIOWE - KAPITAŁ DLA PROJEKTÓW NA PRZYKŁADZIE PLATFORM CROWDFUNDINGOWYCH W POLSCE}

\section{Streszczenie}

Celem głównym artykułu jest analiza funkcjonowania finansowania społecznościowego projektów oraz społecznego postrzegania tego procesu w Polsce. Celem szczegółowym badań jest potwierdzenie sześciu postawionych hipotez dotyczących finansowania społecznościowego lub zaprzeczenie im. Wykorzystano metodę sondażu diagnostycznego oraz metody statystyczne, a także technikę ankietowania i badania dokumentów. Ankieta miała postać internetową i bezpośrednią. Badano również dokumenty elektroniczne portalu Wspieram.to. Pozytywnie zostało zweryfikowanych pięć hipotez.

Słowa kluczowe: finansowanie społecznościowe, projekty, www.wspieram.to Kody JEL: O16, O3, G23

\section{Cytowanie}

Szewczyk, A. (2019). Social financing - capital for projects of the example of crowdfunding platforms in Poland. Studia i Prace WNEiZ US, 55, 111-125. DOI: 10.18276/ sip.2019.55-10. 